\title{
Optimization of the Window Design in Offices for a Proper Circadian Stimulus: Case Study in Madrid
}

\author{
M.A. Campano, M. T. Aguilar, J. Fernández-Agüera, and S. Domínguez
}

\begin{abstract}
The circadian rhythms, endogenous cycles that repeat almost every 24 hours, must be synchronized by daylight stimuli, particularly due to its short wavelength fraction. In this way, insufficient exposure to daylight or its spectral equivalent in electric lighting can endanger human health.

The main aim of this research is to develop a methodology in which circadian stimulus (CS) values can assist to the choice of an office window design, in order to promote a good circadian rhythm and to benefit human health and well-being.

A room model located in Madrid is presented as a study case, having different variables such as the window measures or the environment reflectance values.

It is concluded from the results of this study case that CS and SPD are highly conditioned by the indoor environment reflectance and therefore, also affects to the minimum window size.
\end{abstract}

Index Terms-Circadian stimulus, daylight, window, lighting simulation, office.

\section{INTRODUCTION}

Several studies have demonstrated that light affects not only visual and thermal comfort in interior buildings [1]-[4] but also human health and well-being, including the harmful effects of the circadian rhythm disruption on human health [5]-[7]. They have been also shown the notable influence of light, specifically daylight, on these cycles, given that the light perceived by humans greatly influences the melatonin regulation, a hormone responsible for synchronizing the circadian rhythm [8]. In this way, light does not affect the circadian system and the visual system in the same way. The threshold for stimulation of the circadian system is higher than the visual system due to the greater sensitivity at shorter wavelengths of the first one [9], [10]. Moreover, the response of the human circadian system to light stimulus is slower.

Daylight is the most appropriate light source to have a good circadian entrainment. Currently, people stay more time indoors than outdoors, putting their health at risk. According to this, an optimal window design becomes essential, given that it does not only benefit human health but also it contributes to energy saving by reducing electric lighting energy consumption [11]-[15].

Therefore, new metrics such as the circadian stimulus (CS) have had to be developed. The CS determines levels of light-induced nocturnal melatonin suppression after 1 hour of

Manuscript received December 30, 2018; revised March 1, 2019. This work was supported by the research and development project 'Efficient design for biodynamic lighting to promote the circadian rhythm in offices buildings' (ref BIA2017-86997-R), as well as the TEP-130 Research group.

M. A. Campano, M. T. Aguilar, J. Fernández-Agüera and S. Dominguez are with the Department of Building Construction I, Universidad de Sevilla, Spain (e-mail: mcampano@us.es, maragucar3@alum.us.es, jfernandezaguera@us.es, sdomin@us.es). exposure and a $2.3 \mathrm{~mm}$ diameter pupil. This metric can be quantified using the model of phototransduction proposed by Rea et al. [8]. It have been proved in the latest investigations carried out by Figueiro et al. [7] that an exposure to a CS of 0.3 during the morning is suitable for humans to synchronize properly the circadian rhythm.

\section{OBJECTIVES}

The main aim of this study is to present a methodology which serves to determine the window size that is appropriate for office workers to receive a suitable CS value, in order to promote circadian synchronization, which improves human health and well-being. As a study case for this methodology, an office located in Madrid and facing north is used to generate a calculating model with DaySim tool, analysing the influence of different window dimensions.

As a second objective, this study analyses the impact of the reflectance values of the inner surfaces regarding the aforementioned window size.

\section{Methodology}

\section{A. Selecting the Room Model}

The office under study is a room $8.0 \mathrm{~m}$ wide by $8.0 \mathrm{~m}$ deep by $3.0 \mathrm{~m}$ high. Fig. 1 illustrates all variables of the calculation model. A sole $7.0 \mathrm{~m}$ long window with a variable height is centred in the north façade. The double-leaf window is 0.05 $\mathrm{m}$ thick with a visible light transmittance value of 0.75 .

Calculations were carried out using two inner surfaces average reflectance, taking into account a diffuse reflection. Not all possible room configurations have been studied at the present paper but it aimed to show a typical office as a study object. Therefore, 4 models have been calculated as shown in Table I. Three different work plane surfaces were selected whose reflectance values per wavelength are shown in Figure 2: white (W), light wood (LW) and light blue (LB).

\section{B. Selecting the Calculation Conditions}

The location of the virtual office chosen to perform the analysis was Madrid, Spain, where clear skies predominate. The Spanish National Institute of Meteorology (AEMET) SWEC file [16] was selected to define the weather data. Table 2 shows the average climate conditions of Madrid [17] used to establish the average spectral power distribution (SPD). A CIE D90 is considered for blue skies and a CIE D50 for overcast skies.

As can be seen in Fig. 3, the average SPD of Madrid is lightly higher for short-wavelength than the CIE D65. It is also shown the SPDs resultants from the reflection of the daylight in the three different work planes. 


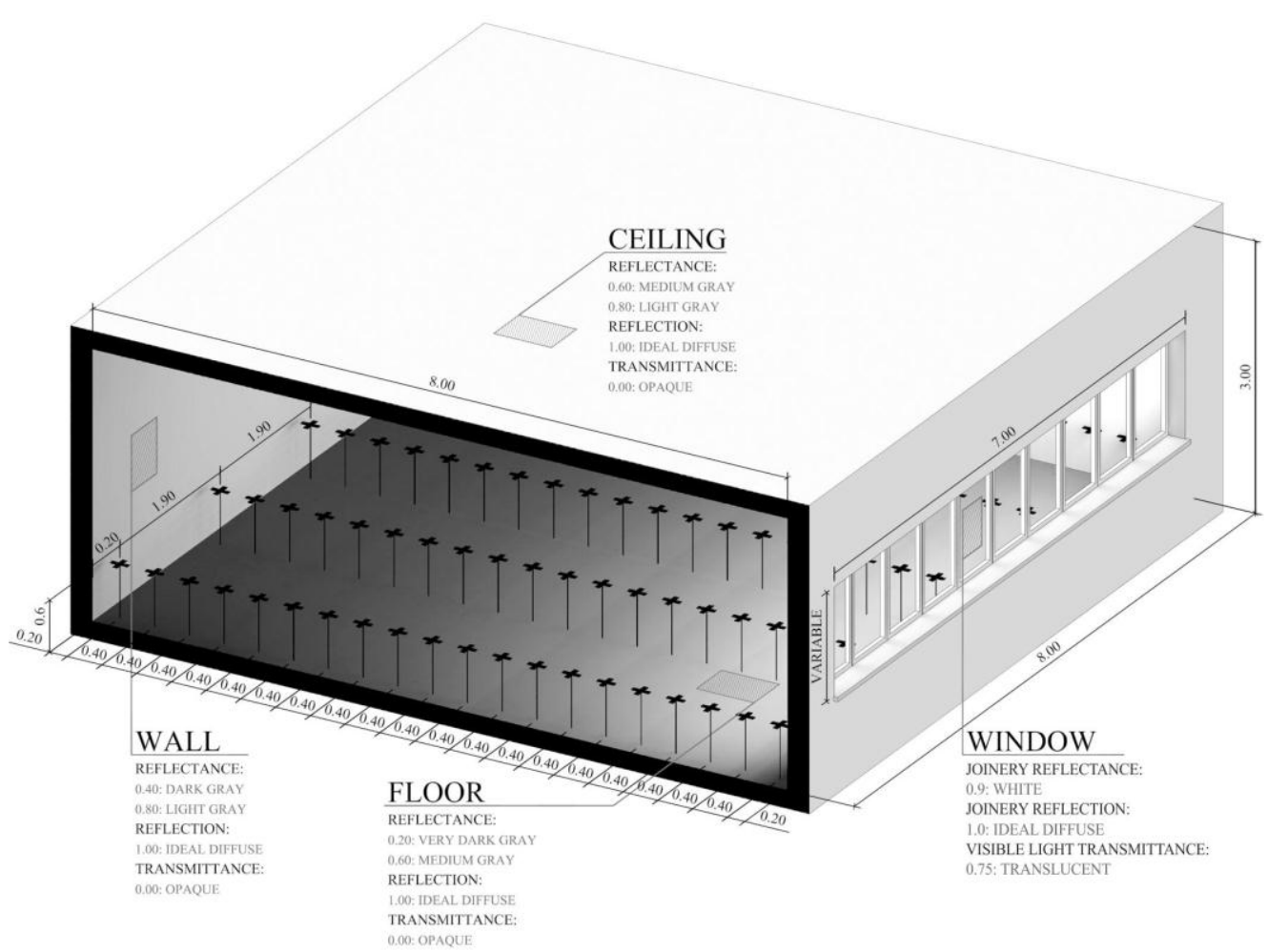

Fig. 1. Office room model.

RESULTING SPECTRAL POWER DISTRIBUTION OF MADRID

ACCORDING TO STATTSTICAL DATA OF NOAA AND PERCENTAGE OF OVERCAST SKIES THROUGHOUT

THE YEAR MODIFIED BY THE REFLECTANCE OF THE WORK PLANE.

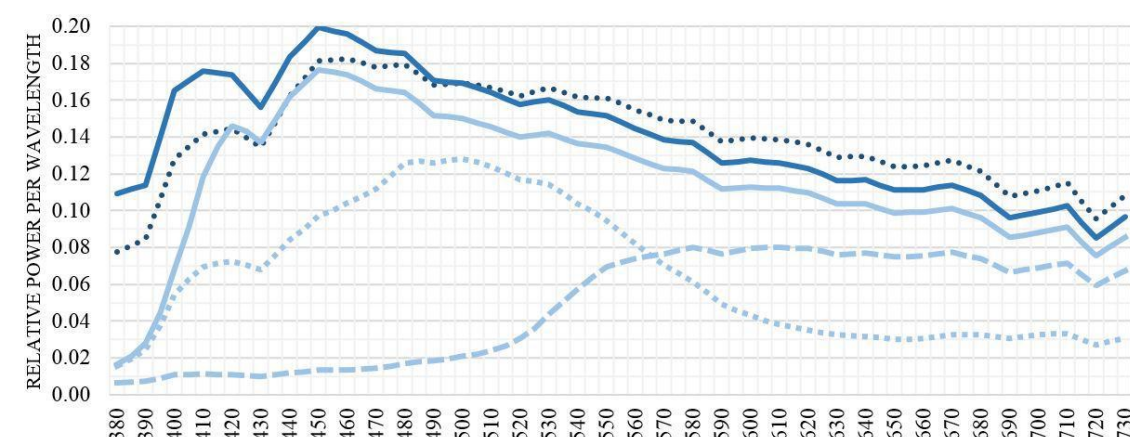

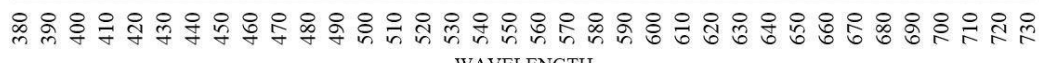

WAVELENGTH

-..... AVERAGE SPD CIE D65

- MADRID (Light WOOD)

AverAge SPD MADRID

MADRID (WHITE)

Fig. 2. Resulting spectral power distribution of Madrid.
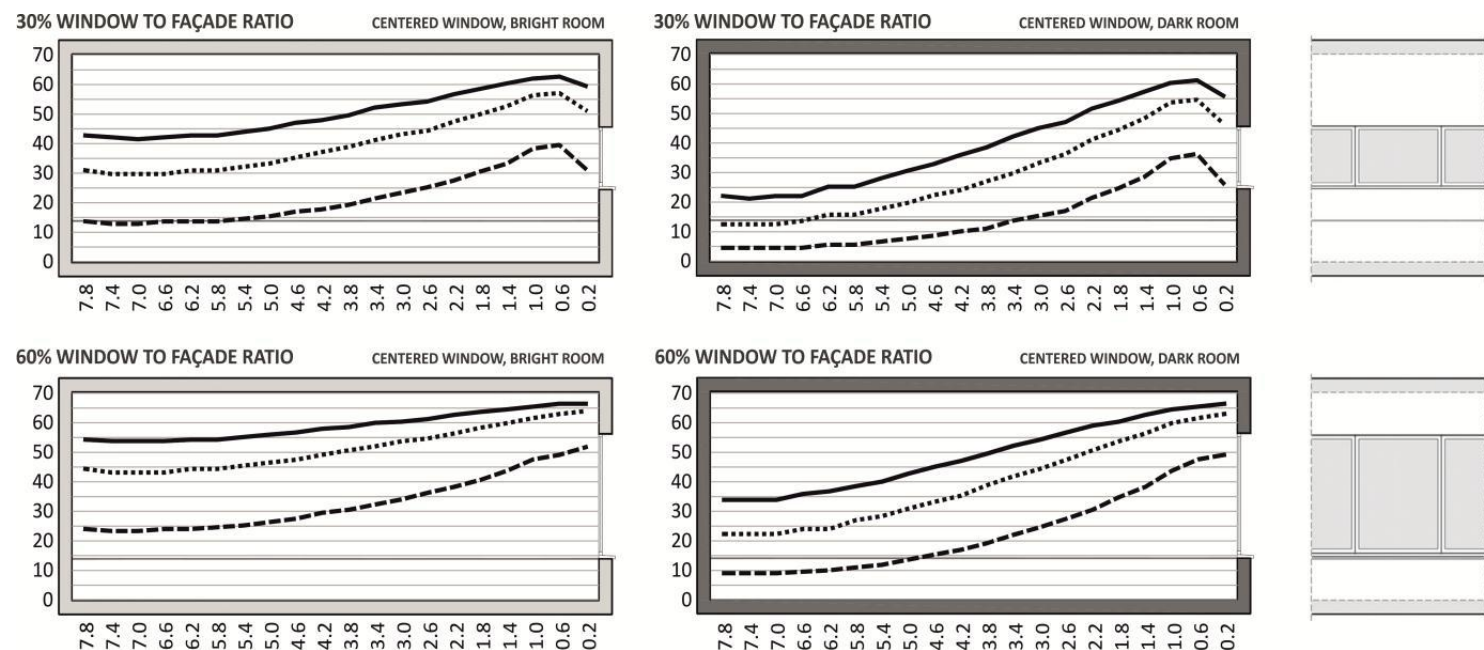

-AVERAGE CIRCADIAN STIMULUS FOR WHITE WORK PLANE
---AVERAGE CIRCADIAN STIMULUS FOR LIGHT WOOD WORK PLANE
-...-AVERAGE CIRCADIAN STIMULUS FOR LGHT BLUE WORK PLANE

Fig. 3. Average Circadian stimulus for an office room with two inner reflectence values and windows to façade ratios. 
TABLE I: CALCULATION MODELS ACCORDING TO VARIABLES ESTABLISHED

\begin{tabular}{lccccccccc} 
Model & $\begin{array}{c}\text { Window/ } \\
\text { facade }\end{array}$ & $\begin{array}{c}\text { Window } \\
\text { surface } \\
\left(\mathrm{m}^{2}\right)\end{array}$ & $\begin{array}{c}\text { Window } \\
\text { width. } \\
\text { height }(\mathrm{m})\end{array}$ & $\begin{array}{c}\text { Glass } \\
\text { surface } \\
\left(\mathrm{m}^{2}\right)\end{array}$ & $\begin{array}{c}\text { Window } \\
\text { position }\end{array}$ & $\begin{array}{c}\text { Visible } \\
\text { Solar } \\
\text { transmittance }\end{array}$ & $\begin{array}{c}\text { Walls } \\
\text { reflectance }\end{array}$ & $\begin{array}{c}\text { Floor } \\
\text { reflectance }\end{array}$ & $\begin{array}{c}\text { Ceiling } \\
\text { reflectance }\end{array}$ \\
\hline $\mathbf{3 0 C B}$ & $30 \%$ & 7.00 & $7.00 \cdot 1.00$ & 5.80 & Centered & 0.75 & 0.8 & 0.6 & 0.8 \\
\hline $\mathbf{3 0 C D}$ & $30 \%$ & 7.00 & $7.00 \cdot 1.00$ & 5.80 & Centered & 0.75 & 0.4 & 0.2 & 0.6 \\
\hline $60 \mathrm{CB}$ & $60 \%$ & 14.00 & $7.00 \cdot 2.00$ & 12.25 & Centered & 0.75 & 0.8 & 0.6 & 0.8 \\
\hline $\mathbf{6 0} \mathrm{CD}$ & $60 \%$ & 14.00 & $7.00 \cdot 2.00$ & 12.25 & Centered & 0.75 & 0.4 & 0.2 & 0.6 \\
\hline
\end{tabular}

\section{Selecting the Calculation Metrics}

TABLE II: AVERAGE CLIMATE CONDITIONS OF MADRID

\begin{tabular}{cccccc}
\hline Location & Rain & Snow & Storm & Fog & Hail \\
\hline Madrid & 114.11 & 5.62 & 19.73 & 21.40 & 1.25 \\
\hline
\end{tabular}

The SPD and the illuminance levels received by workers are the variables that condition the CS values produced by daylight. CS magnitudes were obtained from the calculated circadian light $\left(\mathrm{CL}_{\mathrm{A}}\right)$ values using the equation (1) of the model of human circadian phototransduction, carried out by Rea et al. [8].

$$
C S=0.7 \cdot\left(1-\frac{1}{1+\left(\frac{C L_{A}}{355.7}\right)^{1.1026}}\right)
$$

A CS value of 0.3 during the morning is determined by Figueiro et al. [5] as a suitable one in order to have a good circadian synchronization. Taking it into account, the illuminance thresholds required to promote a CS value of 0.3 had been calculated from the SPDs shown in Fig. 3 and equation 1 , as can be seen in Table III.

TABLE III: ILLUMINANCE REQUIRED IN THE WORK PLANE TO PROMOTE A CS VALUE OF 0.3 ACCORDING TO THE RESUlting SPD PRODUCED BY DIFFERENT SKY CONDITIONS AND THE REFLECTANCE VALUES OF THE ENVIRONMENT

\begin{tabular}{|c|c|c|c|c|c|c|c|c|c|c|}
\hline \multirow{2}{*}{ Location } & \multirow{2}{*}{$\begin{array}{l}\text { Circadian } \\
\text { Stimulus }\end{array}$} & \multicolumn{3}{|c|}{ White work plane (W) } & \multicolumn{3}{|c|}{ Light Wood work plane (LW) } & \multicolumn{3}{|c|}{ Light Blue work plane (LB) } \\
\hline & & E eye & Reflectance & E plane & E eye & Reflectance & E plane & E eye & Reflectance & E plane \\
\hline Madrid & 0.3 & $155 \mathrm{~lx}$ & 0.83 & $186 \mathrm{~lx}$ & $390 \mathrm{~lx}$ & 0.39 & $996 \mathrm{~lx}$ & $152 \mathrm{~lx}$ & 0.44 & $343 \mathrm{~lx}$ \\
\hline
\end{tabular}

According with illuminance values shown above, it can deduced that light blue work plane generates the lowest illuminance received at the eye level of workers with which a specific CS value is reached. Despite that, a white work plane is the optimal surface for the promotion of a suitable CS value since it requires a lower illuminance on the work plane than the light blue one: 186 lx required by the white work plane versus $343 \mathrm{~lx}$ required by the light blue.

\section{Selecting the Calculation Program}

DAYSIM 3.1 and Diva for Rhino are tested Radiance based daylighting analysis software that use a daylight coefficient approach linked with the Pérez all-weather sky model [18] to quantify the amount of daylight, based on direct normal and diffuse horizontal irradiances taken from a climate file. DAYSIM was developed to provide more accurate results than that provided by Radiance in its original form. This tool has been tested by several researchers [19][20]. Table 4 shows the calculation parameters used by this programme in this study.

The use of this lighting software and dynamic metrics have been validated with a study carried out through experimental trials with a test cell [21]-[23].

\section{ANALYSIS OF RESULTS}

Fig. 4 shows the average CS measured at the study points under the variables established in the methodology previously described. CS values are shown for two different window sizes: $30 \%$ and $60 \%$ of the façade area. The results of the calculation model with bright surfaces can be seen in the left side of the figure, while the results of the calculation model with dark surfaces are in the right side.
As expected, the closer to the window, the higher the CS values are and the further away from the window, the more the CS values decrease [10]. As shows Figure 4, there is a linear tendency if the CS results from the two different windows are compared, although the CS values are not directly proportional to the window size. The largest window - a $60 \%$ ratio - promotes an increase in the average CS value of around a $33 \%$ compared to the window to façade ratio of $30 \%$.

TABLE IV: PARAMETERS OF THE DAYSIM 3.1 PROGRAM

\begin{tabular}{ll}
\hline Parameter & Value \\
\hline Ambient Bounces & 7 \\
\hline Ambient Divisions & 1500 \\
\hline Ambient Super-samples & 100 \\
\hline Ambient Resolution & 300 \\
\hline Ambient Accuracy & 0.05 \\
\hline Limit Reflection & 10 \\
\hline Specular Threshold & 0.0000 \\
\hline Specular Jitter & 1.0000 \\
\hline Limit Weight & 0.0040 \\
\hline Direct Jitter & 0.0000 \\
\hline Direct Sampling & 0.2000 \\
\hline Direct Relays & 2 \\
\hline Direct Pre-test Density & 512 \\
\hline
\end{tabular}

As can be seen in the room section of the Fig. 4, CS values are conditioned by the SPD generated by the environment reflectance. A white work plane generates a CS value between $5 \%$ and $80 \%$ higher than the light blue work plane and the increase is much greater when it is compared with the light wood work plane - between $30 \%$ and $305 \%$ higher. 
The results shown in Fig. 4 have been taken into account to sum up in Table $\mathrm{V}$ the minimum window to façade ratio required to promote a suitable $\mathrm{CS}$ - that means a $\mathrm{CS}$ value equal or higher than 0.3 .

As shows Table V, an office with low reflectance levels of the inner surfaces or the work plane hardly promoted a CS value equal or higher than 0.3 despite the window measures. According with that, a light wood work plane (LW) does not facilitate the synchronization of the circadian rhythm. Thus, it is concluded that the work plane must be white (W) or light blue (LB) in order to provide a suitable CS value.

TABLE V: MinimUM Window TO FAÇADE RATIO TO OBTAIN AN Average CS VAlue Higher Than 0.3 DURING THE MORNING

\begin{tabular}{lcccccc}
\hline \multirow{2}{*}{ Location } & \multicolumn{3}{c}{ Bright inner surfaces } & \multicolumn{3}{c}{ Dark inner surfaces } \\
& W & LW & LB & W & LW & LB \\
\hline Madrid & $30 \%$ & - & $45 \%$ & $60 \%$ & - & - \\
\hline
\end{tabular}

\section{CONCLUSIONS}

An exposure to insufficient CS values compromises human health and well-being, so the achievement of an appropriate value for this indicator indoors must be consider during the building design process. In this way, this study has presented a methodology that allows to optimize the windows size in offices, as well as to evaluate the impact of the indoor environment reflectance, using as an example a study case located in Madrid.

According with the analysis of results, the CS highly depends on window dimensions and reflectance levels both of the inner surfaces and of the work plane. In this way, an office with low reflectance levels of the environment hardly promoted a CS value equal or higher than 0.3 despite the window dimensions. It is also deduced from Table 5 that only a white or light blue work plane provides a suitable CS value.

For the variables established in this study and with a white work plane a window to façade ratio of $30 \%$ is required. In conclusion, it can be summarized that environment reflectance plays an important role in CS promotion so it must be taken into account in architectural design.

\section{ACKNOWLEDGMENT}

The results presented were funded by the government of Spain through the research project: Efficient design for biodynamic lighting to promote the circadian rhythm in shift work centers (Ref BIA2017-86997-R). The authors wish to express their gratitude for all the technical and financial support provided.

\section{REFERENCES}

[1] S. S. Korsavi, Z. S. Zomorodian, and M. Tahsildoost, "Visual comfort assessment of daylit and sunlit areas: A longitudinal field survey in classrooms in Kashan, Iran," Energy Build., vol. 128, pp. 305-318, 2016.

[2] M. A. Campano, J. J. Sendra, and S. Domínguez, "Analysis of thermal emissions from radiators in classrooms in Mediterranean climates," Procedia Eng., vol. 21, pp. 106-113, 2011.

[3] M. A. Campano, I. Acosta, J. J. Sendra, and J. Fernández-Agüera, "Towards finding the optimal location of a ventilation inlet in a roof monitor skylight, using visual and thermal performance criteria, for dwellings in a Mediterranean climate," J. Build. Perform. Simu., vol. 8, no. 4, pp. 226-238, 2014.
[4] I. Acosta, M. Á. Campano, and J. F. Molina, "Analysis of energy savings and visual comfort produced by the proper use of windows," Int. J. Eng. Technol., vol. 8, no. 5, pp. 358-365, 2016.

[5] M. S. Rea, A. Bierman, M. G. Figueiro, and J. D. Bullough, "A new approach to understanding the impact of circadian disruption on human health," J. Circadian Rhythms, vol. 6, pp. 1-14, 2008.

[6] P. R. Boyce, "Review: The impact of light in buildings on human health," in Indoor and Built Environment, 2010, vol. 19, no. 1, pp. 820.

[7] M. G. Figueiro et al., "The impact of daytime light exposures on sleep and mood in office workers," Sleep Heal., vol. 3, no. 3, pp. 204-215, 2017.

[8] M. S. Rea, M. G. Figueiro, J. D. Bullough, and A. Bierman, “A model of phototransduction by the human circadian system," Brain Res. Rev. vol. 50, no. 2, pp. 213-228, 2005.

[9] G. C. Brainard et al., "Action spectrum for melatonin regulation in humans: evidence for a novel circadian photoreceptor.," J. Neurosci., vol. 21 , no. 16 , pp. 6405-12, 2001.

[10] K. Thapan, J. Arendt, and D. J. Skene, "An action spectrum for melatonin suppression: Evidence for a novel non-rod, non-cone photoreceptor system in humans," J. Physiol., vol. 535, no. 1, pp. 261267, 2001.

[11] R. P. Leslie, R. Raghavan, O. Howlett, and C. Eaton, "The potential of simplified concepts for daylight harvesting," Light. Res. Technol., vol. 37 , no. 1 , pp. $21-40,2005$.

[12] I. Acosta, M. Á. Campano, and J. F. Molina, "Window design in architecture: Analysis of energy savings for lighting and visual comfort in residential spaces," Appl. Energy, vol. 168, pp. 493-506, 2016.

[13] P. Ricciardi and C. Buratti, "Environmental quality of university classrooms: Subjective and objective evaluation of the thermal, acoustic, and lighting comfort conditions," Build. Environ., vol. 127, no. August 2017, pp. 23-36, 2018.

[14] I. Acosta, C. Muñoz, M. A. Campano, and J. Navarro, "Analysis of daylight factors and energy saving allowed by windows under overcast sky conditions," Renew Energ., vol. 77, pp. 194-207, 2015.

[15] I. Acosta, M. A. Campano, P. Bustamante, and J. F. Molina, "Smart controls for lighting design: Towards a study of the boundary conditions," Int. J. Eng. Technol., vol. 10, no. 6, pp. 481-486, 2018.

[16] F. J. S. de la Flor, S. Á. Domínguez, J. L. M. Félix, and R. G. Falcón, "Climatic zoning and its application to Spanish building energy performance regulations," Energy Build., vol. 40, no. 10, pp. 1984 1990, 2008.

[17] National oceanic and atmospheric administration (NOAA): Statical weather and climate infotmation. (2018). [Online]. Available: https://www.ncdc.noaa.gov/climate-information/statistical-weather-an d-climate-information

[18] R. Perez, R. Seals, and J. Michalsky, "All-weather model for sky luminance distribution-Preliminary configuration and validation," Sol. Energy, vol. 50, no. 3, pp. 235-245, 1993.

[19] C. F. Reinhart and O. Walkenhorst, "Validation of dynamic RADIANCE-based daylight simulations for a test office with external blinds," Energy Build., vol. 33, no. 7, pp. 683-697, 2001.

[20] L. Bellia, A. Pedace, and F. Fragliasso, "The impact of the software's choice on dynamic daylight simulations' results: A comparison between daysim and 3ds Max Design ${ }^{\circledR}$," Sol. Energy, vol. 122, pp. 249-263, 2015.

[21] M. A. Campano, I. Acosta, A. L. León, and C. Calama, "Validation study for daylight dynamic metrics by using test cells in mediterranean area," Int. J. Eng. Technol., vol. 10, no. 6, pp. 487-491, 2018.

[22] A.L. León, R. Suárez, P. Bustamante, M. A. Campano, and D. Moreno, "Design and performance of test cells as an energy evaluation model of facades in a mediterranean building area," Energies, vol. 10, no. 11, pp. 1816 1-16, 2017.

[23] J. Santamaria, S. Giron, and M. A. Campano, "Economic assessments of passive thermal rehabilitations of dwellings in Mediterranean climate," Energy and Buildings, vol. 128, pp. 772-784, 2016.

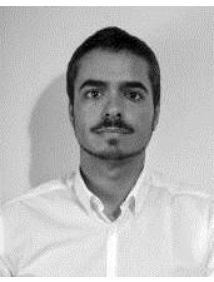

M. A. Campano is a professor at the Department of Building Construction I, University of Seville, Spain. $\mathrm{He}$ is a member of the research group TEP-130, which is focused on sustainability, energy efficiency, lighting, acoustics and optics related to building design and heritage refurbishment.

He develops research on the field of energy efficiency, indoor environmental comfort and daylighting, as well as their relationship with the architectural design. 


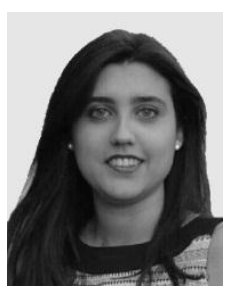

M.T. Aguilar studied Architecture at the University of Seville.

She is a scholarship researcher at the Department of Building Construction I, University of Seville, Spain. She develops research on the field of lighting and its relationship with the architectural design and human health.

J. Fernández-Agüera is a postdoctoral researcher in Department of Building Construction I at the University

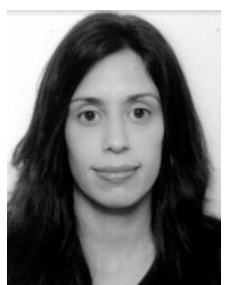
of Seville, Spain. She is a member of the research group TEP-130. Her research focuses on energy efficiency, low-energy buildings, airtightness, indoor air quality and ventilation, with special interest in the interaction between environmental parameters, health and thermal comfort in dwellings.

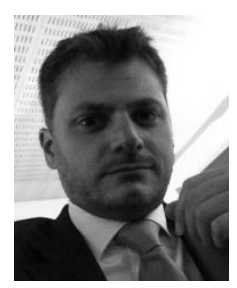

S. Dominguez is a vice dean in the College of Architecture and a professor in Department of Building Construction I at the University of Seville, Spain. He is a member of the research group TEP-130. In his professional career he acts as Expert Consultant on Hi-performance systems for buildings and in the assessment of sustainability and energy efficiency of buildings and their urban environment. $\mathrm{He}$ has extensive background as adviser on environmental control for cultural heritage, with a wide portfolio of national and international projects. 